\title{
Artikelskrivning som eksamensform
}

\author{
Lars Domino Østergaard, adjunkt, Aalborg Universitet, Institut for Læring og Filo- \\ sofi.
}

Diana Stentoft, adjunkt, Aalborg Universitet, Institut for læring og Filosofi.

\section{Reviewet artikel}

\begin{abstract}
I denne artikel vil vi diskutere, hoordan studerendes arbejde med udformning af en videnskabelig artikel som afsæt for summativ evaluering af undervisningsmoduler, kan bidrage såvel til de studerendes oplevelse af motivation som til oplevelse af, at de gives muligheder for at udvikle konkrete akademiske kompetencer. Vi tager udgangspunkt $i$ en række teoretiske overvejelser, der knytter den summative evaluering til begreber som autentiske rammer, kompetenceudvikling og motivation. Disse overvejelser supplerer vi med resultaterne af en konkret undersøgelse af et pilotforsøg gennemført ved 2. semester på kandidatuddannelsen i Idræt på Aalborg Universitet. I relation til to kursusmoduler har de studerende udarbejdet en videnskabelig artikel med afsæt $i$ indsamlet empiri. Undersøgelsen viser, at de studerende i altovervejende grad er positive over for artikelskrivning som udgangspunkt for deres evaluering. Undersøgelsen viser videre, at de studerende oplever en folelse af motivation ved bl.a. at arbejde med selvvalgte problemstillinger. Hvorvidt de studerende faktisk udviklede kompetencer i forløbet, som de ikke kunne udvikle ved andre evalueringsformer, er fortsat ikke afdækket men vil være et naturligt næste genstandsfelt for undersøgelse.
\end{abstract}

\section{Introduktion}

Tilrettelæggelse af eksamensformer, der tilbyder fortsat udvikling af kompetencer, og som samtidig virker meningsfulde og motiverende, er en udfordring i det danske uddannelsessystem. På de følgende sider vil vi med udgangspunkt i begreberne autentiske rammer, kompetenceudvikling og motivation diskutere, hvordan studerendes arbejde med udformning af en videnskabelig artikel, som afsæt for summativ evaluering, kan bidrage såvel til den studerendes oplevelse af motivation som til fortsat udvikling af akademiske kompetencer. Vi følger diskussionen op med præsentation af en undersøgelse af studerende ved 2. semester på kandidatuddannelsen i Idræt ved Aalborg Universitet og deres oplevelser i forbindelse med eksamen. Afslutningsvis peger vi på områder, der forsat kræver afdækning for til fulde at forstå artikelskrivning som eksamensform. 


\section{Eksamen og autenticitet}

"Assessment is probably the most important thing we can do to help our students learn. (Brown, 2005, s. 91).

Noget af det mest centrale for studerende på et universitetsstudie er eksamen, hvor tilegnelse af viden, færdigheder og kompetencer evalueres (Gibbs \& Simpson, 2005). Eksamen og eksamenskrav fungerer ofte som en rettesnor for de studerende og har stor indflydelse på, hvordan studerende vælger at arbejde med fagets mål og undervisningens aktiviteter (Andersen \& Tofteskov, 2008).

De studerendes udvikling af kompetencer er et af de centrale elementer i alignmentprincippet introduceret af John Biggs og kollegaer (Biggs \& Tang, 2007). Princippet kan ses som udtryk for den sammenhæng, der bør være mellem studiets opbygning, brug af undervisnings- og læringsformer, valg af evalueringsformer og ikke mindst den studerendes læringsudbytte. Princippet er udbredt mange steder i undervisningsverdenen og anvendes ofte ukritisk, hvilket Hanne Leth Andersen (2010) problematiserer. Hun påpeger visse udfordringer i anvendelsen af alignmentprincippet, som hun mener, medfører en risiko for generalisering og simplificering i dansk universitetspædagogik med mangel på inspirerende, kreativ og kritisk undervisning som følge heraf. Med reference til Shaffers epistemiske rammebegreb (fx Shaffer, 2005), der vægter de studerendes kompetencer til at bruge det, de har lært i et fag, i forbindelse med en senere faglighed, mener hun, at undervisningen i højere grad bør indebære noget nyt og sættes i relation til deltagerne og til forskellige hændelser omkring dem:

"De studerende har brug for træning $i$ de konkrete færdigheder, de forventes at udvikle, og der er større chance for, at de satser på at udvikle netop disse fxrdigheder, hvis eksamen netop prøver i dem." (Andersen, 2010, s. 34).

Shaffers epistemiske rammebegreb bygger på Lave og Wengers teori om situeret læring og læring i praksisfællesskaber (Lave \& Wenger, 1991; Wenger, 1998), og fremhæver, at det netop er i situationen, at individer (studerende) lærer at tænke og agere i relation til den faglighed, de via deres uddannelse er tænkt ind i. Shaffer siger således:

"Fremfor at konstruere et pensum, der bygger på den faktuelle viden, [...] forestiller jeg mig et system, hvor de studerende lærer at arbejde og tænke som læger, advokater, arkitekter [...] Ikke for at skole de studerende i traditionel forstand men for at udvikle epistemiske rammer, hoori de fär mulighed for at anskue deres viden i relation til en konkret virkelighed med relevante problemstillinger og ved brug af fagfaglige fxrdigheder." (oversat af forfatterne, Shaffer, 2005, s. 2). 
Shaffer lægger altså op til, at de studerende skal arbejde og evalueres inden for epistemiske og autentiske rammer, der for idrætsstuderende kan være forskningsrettede aktiviteter, konsulentopgaver i idrætsorganisationer eller andre jobfunktioner, hvor det at formidle kort, præcist og på velunderbyggede teoretiske og empiriske grundlag er centralt. Det medfører en udfordring for den pædagogiske praksis, hvor undervisningsaktiviteterne skal tilrettelægges, så de i højere grad afspejler autenticitet frem for at fokusere på kontekstuafhængige enkeltelementer, der ikke umiddelbart har relation til den virkelighed, de studerende efterfølgende skal agere i. Følgelig må evalueringsformen også tilrettelægges med reference til autentiske rammer.

\section{Eksamen og kompetenceudvikling}

Kompetencebegrebet er med indførelsen af den fælles europæiske kvalifikationsramme på de videregående uddannelser (Ladefoged, Mandrup, Jessen, Berg, \& Vinther-Jørgensen, 2007) for alvor kommet på dagsordenen og har fået betydning for tilrettelæggelse af alle universitetsuddannelser. Dette stiller krav om specifik formulering af den viden, de færdigheder og de kompetencer, den studerende forventes at erhverve sig via uddannelsens forskellige faglige elementer, hvilket omfatter såvel fagfaglige som mere generelle akademiske kompetencer (Kompetenceguide, 2011). Hermed bliver kompetenceudvikling helt central for uddannelsernes udformning og i evalueringen af den studerende (Andersen, 2005). Væsentlige spørgsmål i denne anledning er, hvorvidt udvikling af specifikke kompetencer kan understøttes ved anvendelse af specifikke evalueringsformer, samt hvorvidt virkelighedsnære problemstillinger indenfor autentiske rammer, og dermed udviklingen af den studerendes tænkning ind i fremtidig arbejdsfelt, kan inddrages i udformningen af det produkt eller den opgave på baggrund af hvilke, der skal evalueres?

I en gennemgang af hvilke akademiske kompetencer, der udprøves på det humanistiske fakultet, Københavns Universitet, i forbindelse med anvendte eksamensformer (med og uden censur), blev 17 forskellige eksamensformer analyseret i relation til kompetencemål inden for tre overordnede kategorier (Rienecker, 2009). Kategorierne, der i undersøgelsen blev benævnt 'faglige', 'praktiske' og 'personlige ${ }^{1}$ kompetencer, var funderet i Ny Dansk Kvalifikationsramme for videregående uddannelse (Ministeriet for Forskning Innovation og Videregående uddannelser, 2007) og fulgte den gængse litteratur vedrørende akademiske kompetencer og universitetseksamener (se fx Andersen, 2005). Ved at sammenholde de forskellige eksamensformer med specielt de praktiske og personlige kompetencer, som de studerende skulle anvende i forbindelse med eksamen (underforstået at de faglige kompetencer blev udprøvet $i$ alle former for eksamen), kom forfatterne frem til, at det specielt er skriftlige eksamens-

\footnotetext{
${ }^{1}$ De personlige kompetencer kaldes også professionelle eller overførbare (transferable) generalistkompetencer (Rienecker 2009, s.7).
} 
former i form af enten 'bunden skriftlig hjemmeopgave', 'projektorienteret eksamen' eller 'aktiv undervisningsdeltagelse med aktivitet eller produkt', der i størst muligt omfang udprøver og understøtter de studerendes videreudvikling af deres personlige og praktiske kompetencer. Det er tre former, der alle inkluderer mulighed for, at de studerende i arbejdet med eksamensproduktet kan erhverve og anvende viden ud over det, der er gennemgået i faget. En viden som kan støtte og udbygge deres eksamensprodukt og dermed styrke deres muligheder for en positiv evaluering. Det er altså både eksamensformen såvel som arbejdet med eksamensproduktet, der i de tre prøveformer fremhæves i undersøgelsen fra Københavns Universitet, og som viste sig at understøtte de studerendes kompetenceudvikling.

\section{Eksamen, motivation og kompetencer}

Et vigtigt aspekt i de studerendes arbejde med både eksamensprocessen og -produktet er, udover tilegnelsen af kompetencer, deres motivation for at lære.

Motivation er her forstået som den følelse af autonomi, kompetence og tilhørsforhold, som de studerende har i relation til deres arbejde frem mod eksamen (jf. 'Self Determination Theory' som formuleret af Deci, 1992). Hermed anses motivation ikke udelukkende for at være essentiel i forhold til de studerendes engagement i forbindelse med undervisningen men i høj grad også for den videre udvikling af deres akademiske kompetencer (Brophy, 2010).

I et review af forskning omkring eksamen, eksamensformer og motivation, har Harlen og Crick (2003) gennemgået 19 udvalgte studier af eksamen, der fokuserede på den summative bedømmelse og på hvorledes, den påvirker de studerendes motivation for at lære - og hermed for at videreudvikle deres akademiske kompetencer.

På baggrund af de mange undersøgelser, kom Harlen og Crick frem til en række faktorer, der kan have indflydelse på de studerendes motivation for læring (se figur 1).

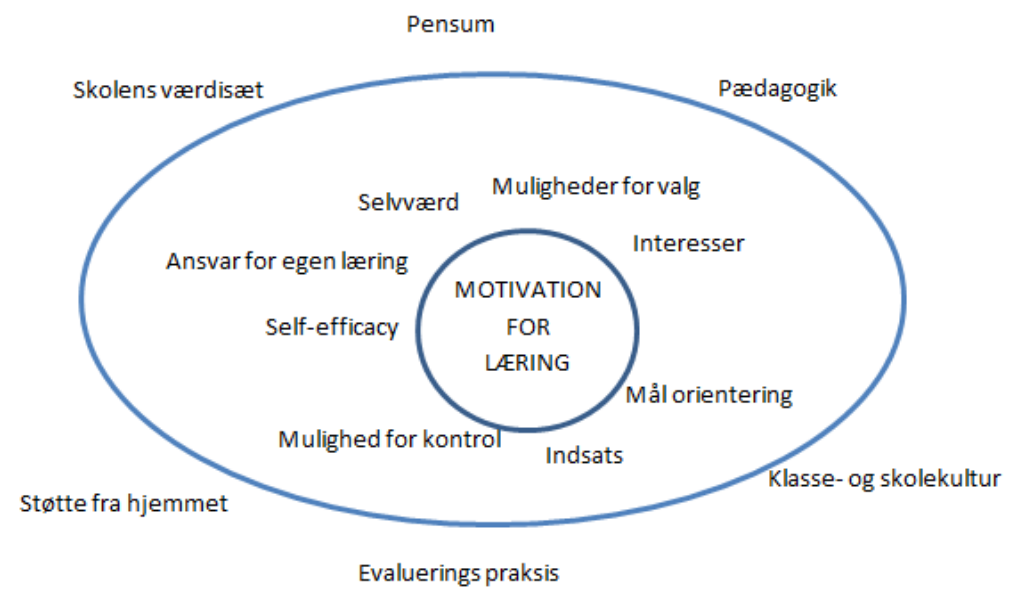

Figur 1. Faktorer der kan påvirke studerende motivation for at lære. Frit efter Harlen og Crick (2003). 
Ser vi på de faktorer, der kan hæmme eller fremme motivationen blandt studerende, er det tydeligt, at der er en vis overensstemmelse mellem studerendes muligheder for at påvirke disse faktorer og de kompetenceudviklende eksamensformer fremhævet af Rienecker (2009). Disse lægger alle op til, at den studerende træffer egne valg, fordyber sig ud fra interesse, tager ansvar for egen læring og sikres mulighed for en vis grad af kontrol. Hvis ovenstående overensstemmelse sammenholdes med forskning, der viser sammenhæng mellem motiverede, engagerede og aktive studerende og deres udvikling af akademiske kompetencer (Andersen, 2005; Brophy, 2010), er det muligt at argumentere for artikelskrivning som evalueringsform, idet denne form ligeledes giver de studerende mulighed for indflydelse på faktorer, der kan motivere til læring.

Således synes den foreslåede evalueringsform umiddelbart rent teoretisk at tilfredsstille en række krav til en motiverende og kompetenceudviklende eksamensform. Velvidende at det ikke er alle de idrætsstuderende, der er i fokus i denne undersøgelse, der i deres kommende ansættelse skal formulere videnskabelige artikler, vil vi dog argumentere for, at formen med en kort og præcis analyse, syntese og konklusion baseret på teoretiske og empiriske data i relation til en idrætsrelateret problemstilling i autentiske rammer ${ }^{2}$ er relevant. Med en gentagelse af Shaffers ord giver det de studerende "mulighed for at anskue deres viden i relation til en konkret virkelighed med relevante problemstillinger og ved brug af fagfaglige færdigheder" (oversat af forfatterne, Shaffer, 2005, s. 2).

\section{Undersøgelsens baggrund og udformning}

En problembaseret tilgang til læring er gennemgående ved alle studier på Aalborg Universitet, (Kolmos, Fink \& Krogh, 2004). Den problembaserede læringstilgang er nært forbundet med projektarbejdsformen som arena for læring og sigter blandt andet mod udvikling af akademiske kompetencer. Det tilstræbes bl.a., at studerende kan arbejde med virkelighedsnære og selvvalgte problemstillinger i såvel projekter som øvrige undervisningssammenhænge (Kompetenceguide, 2011). Fokus på studentercentreret undervisning samt fokus på udvikling af akademiske kompetencer giver anledning til løbende overvejelser vedrørende sammenhænge mellem fagfagligt stof, virkelighedsnære problemstillinger, studerendes motivation for læring og mulighederne for udprøvning af studieordningernes mål. Det er sådanne overvejelser, der har givet anledning til introduktionen af 'artikelskrivning' som udgangspunkt for summativ evaluering af kurser på Idræt, kandidatuddannelsen, 2. semester. ${ }^{3}$

\footnotetext{
${ }^{2}$ Fx om hvordan Jan Pytlik og Kim Jensen kan optimere deres arbejde med procesfærdigheder for det danske kvindelandshold (projekt og artikelopgave, Idræt, AAU, 8. semester forår 2011).

${ }^{3}$ Begge forfattere har været med til at udvikle semesterkurserne på idrætsstudiet, 2. semester, kandidatdelen, og den ene forfatter har desuden undervist på modulet Idrætsundervisning, leg og læring, men har ikke været involveret i de moduler, der blev evalueret ved 'artikelskrivning', og har derfor ikke været involveret i bedømmelsen af de afleverede artikler.
} 
Udgangspunktet er, at de studerende igennem deres arbejde med en evalueringsform, der motiverer til engagement og læring, gives mulighed for at udvikle deres akademiske kompetencer og samtidig tilbydes muligheder for at arbejde inden for fagenes autentiske rammer. I den konkrete evalueringsform er det foruden specifikke faglige kompetencer bl.a. følgende kompetencer, de studerende arbejder med:

- kan formidle forskningsbaseret viden og diskutere professionelle og videnskabelige problemstillinger (formidlings- og kommunikationskompetence som en del af den personlige kompetence: Cheetham \& Chivers, 1996; Det sundhedsvidenskabelige fakultet, 2010).

- kan reflektere over viden inden for [coaching] på et videnskabeligt grundlag og kan identificere videnskabelige problemstillinger (analytisk- og navigationskompetence som en del af den personlige kompetence: Det sundhedsvidenskabelige fakultet, 2010; Rienecker, 2009).

- kan selvstændigt igangsætte og gennemføre fagligt og tværfagligt samarbejde og påtage sig professionelt ansvar (samarbejdskompetence som en del af den personlige kompetence: Det sundhedsvidenskabelige fakultet, 2010; Rienecker, 2009).

Disse kompetencer, der blandt andre relaterer til den empiri, de studerende praktisk har indsamlet, indgår således i den samlede profil for kandidatuddannelsen i Idræt ved Aalborg Universitet (Det sundhedsvidenskabelige fakultet, 2010).

Andet semester er opbygget omkring temarammen Projektledelse, læring og coaching. Foruden et valgfrit projektforløb (15 ECTS) indenfor semestrets fastlagte temaramme, omfatter semestret kursusmodulerne (hvert på 5 ECTS) Idrætsundervisning, leg og læring, Coaching, motivation og talentudvikling samt Projektledelse og teambuilding.

På baggrund af den empiri, de studerende indsamlede i forbindelse med deres semesterprojekt, og med reference til den teori, de blev præsenteret for i kursusmodulerne Coaching, motivation og talentudvikling og Projektledelse og teambuilding, skulle de studerende med afsæt $\mathrm{i}$ en selvvalgt problemstilling forfatte en videnskabelig artikel (som beskrevet i Rienecker, Jørgensen \& Gandil, 2009), der dannede grundlag for en samlet summativ evaluering af de to kursusmoduler. ${ }^{4}$

\footnotetext{
${ }^{4}$ Semesterprojektet blev bedømt uafhængigt af kursusmodulerne. Selvom de studerende havde mulighed for at anvende empiri indsamlet ifbm. semestrets projektarbejde, blev der stillet krav om, at de selvvalgte problemstillinger i hhv. semesterprojekt og den videnskabelige artikel var forskellige.
} 
Eftersom de studerende arbejdede gruppevis med deres projekt og dermed med indsamling af empirisk materiale, udarbejdede de artiklen i samarbejde, men påførte en hovedansvarlig for de enkelte afsnit. Artiklen blev bedømt som bestået/ikke bestået på baggrund af de enkelte studerendes præsentation og formidling af indhold, der demonstrerede opfyldelse af kursernes læringsmål. Artiklen havde et omfang på 512 sider afhængigt af antal studerende, der var med til at forfatte artiklen, og skulle opfylde de krav til formalia, der almindeligvis stilles til akademiske publikationer. ${ }^{5}$

Da udformning af en videnskabelig artikel som afsæt for evaluering er en i praksis relativt uprøvet men dog teoretisk set velbegrundet evalueringsform, faldt det naturligt at følge op på de studerendes mere konkrete oplevelser med at udarbejde en artikel. Undersøgelsens sigte var at få en indikation af de studerendes konkrete oplevelser med evalueringsformen og står således som et supplement eller en yderligere dimension til den teoretiske argumentation for at vælge artikelskrivning som afsæt for evaluering.

Undersøgelsen tog udgangspunkt i et spørgeskema der blev opbygget omkring en række udsagn, som de studerende blev bedt om at forholde sig til på en Likert-skala (6 trin) fra 'helt enig' til 'helt uenig'. Udsagnene blev, for de flestes vedkommende, bygget op omkring en række karakteristika omkring det at arbejde med en videnskabelig artikel og fordelte sig inden for fem overordnede temaer med såvel positive som negative udsagn. Hver tematisk blok blev afsluttet med enkelte åbne spørgsmål, hvor respondenten kunne uddybe eller tilføje kommentarer. Besvarelserne inden for de åbne kategorier var sporadiske og gav ikke nogen tydelig indikation og behandles derfor ikke yderligere i denne artikel. De fem temaer var:

- Fordele ved udformning af artikel

- Ulemper ved udformning af artikel

- Udfordringer ved at udforme en artikel

- Oplevelsen af motivation for at skrive en artikel

- Generel holdning til brugen af artikelskrivning som udgangspunkt for evaluering

Det valgte spørgeskemadesign gjorde det muligt at afdække respondenternes holdninger og meninger om et givent emne, i dette tilfælde oplevelsen med at udforme en videnskabelig artikel (Cohen, Manion \& Morrison, 2007). Det er væsentligt at fremhæve, at udsagnene omkring det valgte emne på en Likert-skala må formuleres tydeligt og gerne forholde sig positivt eller negativt til emnet. Dette gøres for at tydeliggøre, hvad respondenterne erklærer sig enig/uenig i og samtidig for at sikre et

\footnotetext{
${ }^{5}$ Det gælder dels opbygning af artiklen, antal ord til abstract, måden at angive referencer på (APA-style) samt andre formalia, der gælder ved udformning af videnskabelige artikler.
} 
design, der gør det muligt at identificere respondenter, der afkrydser ens i alle udsagn uden at reflektere over svaret. En respondent, der erklærer sig delvist enig i alle udsagn, vil således tydeligt komme til at modsige sig selv (Bryman, 2008).

Antallet af mulige respondenter var identisk med den samlede population - de 19 studerende der gennemførte 2. semester på kandidatuddannelsen det pågældende semester. 18 studerende deltog i undersøgelsen. ${ }^{6}$ Spørgeskemaet bestod af 29 udsagn. I ni udsagn valgte en respondent at undlade besvarelse. I et udsagn undlod to respondenter at svare. Dette kan skyldes, at der ikke forekom en 'ved ikke-kategori' i skemaet.

Det lave antal respondenter (men den dog høje svarprocent) betyder, at undersøgelsen kun er retningsgivende for generelle tendenser, som vi dog mener sammenholdt med de teoretiske argumenter for at anvende artikelskrivning som afsæt for evaluering kan give en indikation af denne evalueringsforms anvendelighed. I vores bearbejdning af undersøgelsens resultater har vi valgt primært at vægte de spørgsmål, hvor vi ser en tydelig indikation inden for enten kategorierne 'helt enig/enig' eller 'helt uenig/uenig'. Vi har således gjort nedslag, hvor to tredjedele eller flere af respondenterne placerer sig inden for disse kategorier. Ved kun i begrænset omfang at inddrage besvarelser inden for de mere utydelige og i et vist omfang overlappende svarkategorier 'til dels enig/til dels uenig' ønsker vi at begrænse vores nedslag til de områder, hvor undersøgelsen giver tydelige indikationer på de studerendes oplevelser med artikelskrivning.

\section{Undersøgelsens resultater}

Helt overordnet forholder de 18 respondenter sig overvejende positivt til det at have udformet artikler som afsæt for evaluering. Der ses generelt en tendens til, at respondenterne erklærer sig enige omkring de positive udsagn, ligesom de fortrinsvis erklærer sig uenige i negative udsagn om artikelskrivningen. Nedenfor vil vi fremdrage de steder i undersøgelsen, hvor de studerendes erklæringer er stærkest i forhold til konkrete udsagn.

\section{Fordele ved at skrive en videnskabelig artikel.}

De autentiske rammer i forhold til eksamensproduktet med bl.a. krav til artikellængde og præsentation samt selvstændigt valg af problemstilling fungerede godt for størstedelen af de studerende. Dette ses blandt andet i deres holdning til det at have stramme formelle krav at forholde sig til, samt hvorledes disse krav om struktur påvirkede arbejdet med at udforme artiklen. Ligeledes anså de studerende kravet om at

\footnotetext{
${ }^{6}$ Spørgeskemaet var anonymt og elektronisk distribueret af den ene forfatter. De studerende kunne vælge at aflevere pr. mail eller til underviser/sekretær for at øge anonymiteten. Spørgeskemaet blev besvaret før, artiklerne blev evalueret og dermed inden, de studerende fik feedback på deres arbejde.
} 
formulere sig kort og præcist som fordelagtig, hvilket indikerer, at det ikke oplevedes forstyrrende eller hæmmende, når der i evalueringsformen blev indlagt et arbejde, der understøttede udvikling af formidlingskompetencer.

\begin{tabular}{|l|c|c|c|}
\hline $\begin{array}{l}\text { Det at skrive en videnskabelig artikel, kan ses } \\
\text { som en fordel i forhold til at skrive andre } \\
\text { afleveringsopgaver. Nedenfor vil vi bede dig } \\
\text { om at tilkendegive din holdning til følgende } \\
\text { udsagn (Sæt kryds) }\end{array}$ & Helt enig/ Enig & $\begin{array}{c}\text { Helt uenig/ } \\
\text { Uenig }\end{array}$ & NA \\
\hline $\begin{array}{l}\text { Det var en fordel kun at have et begrænset antal } \\
\text { sider at skrive på }\end{array}$ & $13(72 \%)$ & $0 \%$ & $0 \%$ \\
\hline $\begin{array}{l}\text { Det var en fordel at være tvunget til at } \\
\text { udtrykke sig kort og præcist }\end{array}$ & $14(78 \%)$ & $0 \%$ & $0 \%$ \\
\hline $\begin{array}{l}\text { Den stramme struktur, en videnskabelig } \\
\text { artikel har, gjorde, at det var let at skrive en arti- } \\
\text { kel på baggrund af projektarbejdet. }\end{array}$ & $16(89 \%)$ & $0 \%$ & $0 \%$ \\
\hline
\end{tabular}

Tabel 1. Spørgsmål om fordelene ved at udforme en videnskabelig artikel. Kun spørgsmål, hoor mere end to tredjedele af respondenterne erklærede sig 'enig/helt enig' eller 'uenig/helt uenig', er medtaget. $N A$ udgør respondenter, der ikke har svaret. At den procentvise fordeling ikke altid giver sammenlagt $100 \%$ skyldes, at kategorierne 'til dels enig' og 'til dels uenig' ikke er medtaget. Udvxlgelsen gxlder også for folgende tabeller.

Ulemper ved at skrive en videnskabelig artikel

Et særligt karakteristika ved en videnskabelig artikel er det begrænsede antal sider, der tvinger forfatterne til at definere, udvælge og dokumentere det faglige stof. Ovenfor så vi, at de studerende anså dette for en fordel, og i tabel 2 nedenfor ses det, at der ikke har manglet materialer til at understøtte udformningen af artiklen. Dette indikerer, at de studerende måtte træffe valg om, hvad de ville præsentere. Til udsagnet om, at 'Der var mange pointer fra projektet, som vi desværre ikke fik med i artiklen, da der ikke var sider nok at skrive på', fordeler de studerende sig til gengæld ligeligt mellem erklæringer om enighed og uenighed. Dette indikerer, at nogle, men langt fra alle, følte sig udfordret af på den ene side at skulle omfavne hele deres indsamlede empiri, og på den anden side at skulle skrive en artikel af begrænset omfang.

De valg, de studerende skal træffe i forbindelse med udformningen af en artikel, udprøver deres formidlings- og kommunikationskompetence og understøtter i vid udstrækning de studerendes arbejde inden for autentiske rammer, hvor det er faglighedens betingelser og normer samt tidsskriftformatet med tilhørende formelle krav, der er styrende for den studerendes håndtering af en opgave. Samtidigt fremhæves muligheden for selvstændigt at træffe valg som en faktor, der kan virke motiverende. 


\begin{tabular}{|l|l|c|c|}
\hline $\begin{array}{l}\text { Udover mulige fordele ved at skrive en vi- } \\
\text { denskabelig artikel, er der også nogle mulige } \\
\text { ulemper. Nedenfor vil vi bede dig om at til- } \\
\text { kendegive din holdning til følgende udsagn } \\
\text { (Sæt kryds) }\end{array}$ & Helt enig/ Enig & $\begin{array}{c}\text { Helt uenig/ } \\
\text { Uenig }\end{array}$ & NA \\
\hline $\begin{array}{l}\text { Vi havde ikke nok materiale til at fylde en hel arti- } \\
\text { kel }\end{array}$ & $0 \%$ & $84 \%$ & $0 \%$ \\
\hline
\end{tabular}

Tabel 2. De studerende erklærer sig uenige i ikke at have nok materiale til at udforme en artikel.

\section{Udfordringer ved at udforme en videnskabelig artikel}

Adspurgt om oplevelsen af udfordringer ved at skrive en videnskabelig artikel og de potentielle positive gevinster ved disse udfordringer viste det sig, at de studerende havde en tydelig oplevelse af at have udviklet nye forståelser i forbindelse med arbejdet (se tabel 3 nedenfor). De studerende oplevede via deres arbejde at få større indblik i artiklers opbygning, følte sig bedre rustede til i fremtiden at skrive en videnskabelig artikel og følte dybere indsigt i den (for faget) videnskabelige arbejdsmåde. Samlet set giver disse indikationer indtryk af, at intentionerne om at tilbyde en evalueringsform, der umiddelbart understøtter videre udvikling af de akademiske kompetencer, kan realiseres og anses som berigende af de studerende.

\begin{tabular}{|l|c|c|c|}
\hline $\begin{array}{l}\text { Det at skrive en videnskabelig artikel kan give } \\
\text { mange udfordringer, hvoraf nogle synes at } \\
\text { være nyttige i sig selv, mens andre mere er til } \\
\text { besvær. Nedenfor vil vi bede dig om at tilken- } \\
\text { degive din holdning til følgende udsagn } \\
\text { (Sæt kryds) }\end{array}$ & Helt enig/ Enig & $\begin{array}{c}\text { Helt uenig/ } \\
\text { Uenig }\end{array}$ & NA \\
\hline $\begin{array}{l}\text { Det har givet mig stort indblik } i \text {, hvordan en artikel } \\
\text { er opbygget ved selv at have skrevet en }\end{array}$ & $16(89 \%)$ & $1\left(6 \%{ }^{7}\right)$ & $0 \%$ \\
\hline $\begin{array}{l}\text { Jeg føler mig bedre rustet til at skrive en videnska- } \\
\text { belig artikel en anden gang }\end{array}$ & $15(83 \%)$ & $0 \%$ & $0 \%$ \\
\hline $\begin{array}{l}\text { Jeg har fået større indblik } i \text { den videnskabelige } \\
\text { arbejdsmåde ved at skrive en artikel }\end{array}$ & $13(72 \%)$ & $0 \%$ & $0 \%$ \\
\hline
\end{tabular}

Tabel 3. Oplevelser med udfordringer ved udformning af videnskabelig artikel.

Oplevelse af motivation

Mange af de positive tilkendegivelser om oplevelsen med at skrive en videnskabelig artikel i tabel 1, 2 og 3 kan tolkes i relation til de studerendes motivation. Formelle krav, rammer og mulighed for valg, kan direkte relateres til figur 1 ovenfor som fak-

\footnotetext{
${ }^{7}$ Den studerende skriver som note, at han tidligere har skrevet videnskabelige artikler, så han synes
} ikke, det er en nyerhvervet kompetence. 
torer, der kan have indflydelse på de studerendes oplevelser af motivation. Hertil kommer, at et betydeligt flertal af respondenterne (12 ud af $18=67 \%$ ) erklærer sig enige eller helt enige $i$, at de hellere vil skrive videnskabelige artikler frem for at arbejde med andre former for skriftlige evalueringer som afslutning på moduler.

Derudover er der i artikelskrivningen indlejret både valgfrihed ift. behandlet emne (valgt ud fra egen interesse, men inden for rammerne af de to evaluerede kursusmoduler), lagt op til egen kontrol med processen og til dels også ansvar for fælles og egen læring. Det er parametre, der ligeledes kan knyttes til en oplevelse af motivation. Dette afspejles også i, at samtlige respondenter oplevede det motiverende at skrive om noget, man selv havde arbejdet praktisk undersøgende med (se tabel 4). Såvel arbejdet med egne undersøgelser som muligheden for publicering kan ses som knyttet til fagets autentiske ramme også uden for universitets mure, og det vil være nærliggende i uddybende undersøgelser at se nærmere på, om det netop er denne mulighed for at interagere med fagets faglige praksis på forskellig vis, der faktisk bibringer motivation for arbejdet, selv i en evaluerende situation.

\begin{tabular}{|c|c|c|c|}
\hline $\begin{array}{l}\text { En vigtig parameter for en god evaluerings- } \\
\text { form er, at den kan virke motiverende. Ikke } \\
\text { kun ved at sætte de studerende op til at yde } \\
\text { deres bedste i den aktuelle situation, men } \\
\text { også mht. at øge deres kompetencer fremad- } \\
\text { rettet. De følgende spørgsmål handler dels } \\
\text { om det motiverende ved denne form for } \\
\text { evaluering og samtidig om nogle faktorer, } \\
\text { der kunne virke demotiverende på skrively- } \\
\text { sten. } \\
\text { Nedenfor vil vi bede dig om at tilkendegive } \\
\text { din holdning til det at skrive en videnskabe- } \\
\text { lig artikel. Følgende udsagn omhandler dette } \\
\text { aspekt (Sæt kryds) }\end{array}$ & Helt enig/ Enig & $\begin{array}{l}\text { Helt uenig/ } \\
\text { Uenig }\end{array}$ & NA \\
\hline $\begin{array}{l}\text { a. Det er motiverende, at vi skriver om noget, } \\
\text { vi selv har arbejdet praktisk undersogende } \\
\text { med }\end{array}$ & $18(100 \%)$ & $0 \%$ & $0 \%$ \\
\hline $\begin{array}{l}\text { b. Det er motiverende, at artiklen bliver publi- } \\
\text { ceret, så andre kan læse om vores arbejde }\end{array}$ & $14(78 \%)$ & $0 \%$ & $0 \%$ \\
\hline
\end{tabular}

Tabel 4. Studerendes oplevelse af motivation ved udformning af en videnskabelig artikel.

\section{Konklusion: Er artikelskrivning et relevant afsæt for summativ bedømmelse?}

Samlet set giver undersøgelsen indtryk af, at de studerende forholder sig positivt til at udforme videnskabelige artikler som afsæt for deres summative bedømmelse. Undersøgelsen siger imidlertid ikke noget om, hvorvidt denne eksamensform i autenti- 
ske rammer faktisk har understøttet de studerendes udvikling af specifikke akademiske kompetencer, eller om det har været andre faktorer ved eksamensformen, der har haft positiv indflydelse på deres holdning. Det, vi dog ser, er, at de oplever arbejdet som motiverende, og vi kan argumentere for, at de studerende selv oplever muligheder for at udvikle kompetencer til at arbejde med akademisk materiale. Opsummerende kan det konstateres, at der synes at være sammenhæng mellem på den ene side de teoretiske argumentationer for artikelskrivning som en motiverende og kompetenceudviklende evalueringsform, og på den anden side de studerendes oplevelser af arbejdet med at udforme en videnskabelig artikel. Der er fortsat en række uudforskede aspekter omkring dette afsæt for evaluering, men umiddelbart kan ovenstående indikere, at der med denne arbejdsform åbner sig muligheder for at lade studerende arbejde inden for autentiske rammer, noget som synes særligt relevant på semestre nær afslutningen af et uddannelsesforløb.

Lars Domino Østergaard er ansat som adjunkt på Institut for Læring og Filosofi, Aalborg Universitet, hvor han siden 2010 har undervist på universitetets idrætsuddannelse. Med fokus på forskningsområderne læring og motivation, har han iværksat og været med til at gennemforer forskningsprojekter desangående og har senest været involveret $i$ en større omstrukturering af idrætsuddannelsen på Aalborg Universitet; herunder planlægning af eksamensformer.

Diana Stentoft er adjunkt ved Institut for Læring og Filosofi, Aalborg Universitet, hvor hun underviser og forsker inden for områderne universitetspædagogik og problembaseret læring inden for de sundhedsfaglige universitetsuddannelser.

\section{Litteratur}

Andersen, H. L. (2005). Eksamensformer: Valg med konsekvenser. Center for Undervisningsudvikling, Aarhus Universitet.

Andersen, H. L. (2010). "Constructive alignment" og risikoen for en forsimplende universitespædagogik. Dansk Universitetspædagogisk Tidsskrift, nr. 9.

Andersen, H. L. \& Tofteskov, J. (2008). Eksamen og eksamensformer. Frederiksberg: Samfundslitteratur.

Biggs, J. B. \& Tang, C. (2007). Teaching for quality learning at university. Berkshire: Open University Press.

Brophy, J. (2010). Motivating students to learn. New York: Routledge.

Brown, S. (2005). Assessment for learning. Learning and Teaching in Higher Education, 1.

Bryman, A. (2008). Social research methods. Oxford: Oxford University Press.

Cheetham, G. \& Chivers, G. (1996). Towards a holistic model of professional competence. Journal of European Industrial Training, 20(5).

Cohen, L., Manion, L. \& Morrison, K. (2007). Research methods in education. New York: Routledge. 
Deci, E. L. (1992). The Relation of Interest to the Motivation of Behavior: A Self-

Determination Theory Perspective. I: Rennie, K. A., Hidi, S. \& Krapp A. (eds.), The Role of Interest in Learning and Development. Hillsdale: Lawrence Erlbaum Associates.

Det sundhedsvidenskabelige fakultet. (2010). Studieordning for kandidatuddannelsen $i$ idræt. Aalborg: Aalborg Universitet.

Gibbs, G. \& Simpson, C. (2005). Conditions under which assessment support students' learning. Learning and Teaching in Higher Education, 1.

Harlen, W. \& Crick, R. D. (2003). Testing and motivation for learning. Assesment in Education, 10(2).

Kolmos, A., Fink, F. K. \& Krogh, L. (2004). The Aalborg PBL Model. Aalborg: Aalborg University Press.

Kompetenceguide. (2011). Aalborg Universitetes kompetenceguide. Aalborg: Aalborg Universitet.

Kompetenceveje - inspiration til studienævnene og eksempler på kompetencebeskrivelser. (2004). Kompetenceprojektet ved det Humanistiske Fakultet. København: Det Humanistiske Fakultet, KU.

Ladefoged, A. M., Mandrup, A.-K., Jessen, M.-A., Berg, M. \& Vinther-Jørgensen, T. (2007). Ny dansk kvalifikationsramme. Downloaded 5.3.2013 fra:

http://www.asb.dk/fileadmin/www.asb.dk/tilmedarbejdere/uddannelse/kvalite tssikringafuddannelser/fileexplorer_fetchfile-aspx-file-3726.pdf.

Lave, J. \& Wenger, E. (1991). Situated learning. Cambridge: Cambridge University Press.

Ministeriet for Forskning Innovation og Videregående uddannelser. (2007). Ny dansk kvalifikationsramme for videregående uddannelse. Downloaded 6.3.2013 fra http://fivu.dk/uddannelse-og-institutioner/anerkendelse-ogdokumentation/dokumentation/kvalifikationsrammer/andre/dk-videregaaende

Rienecker, L. (2009). Rapport om eksamensformer på Det Humanistiske Fakultet København. København: Københavns Universitet.

Rienecker, L., Jørgensen, P. S. \& Gandil, M. (2009). Skriv en artikel. København: Forlaget Samfundslitteratur.

Shaffer, D. W. (2005). Epistemic games. Innovate, 1(6).

Wenger, E. (1998). Communities of Practice. Cambridge: Cambridge University Press. 